Crop Breeding and Applied Biotechnology 13: 194-199 2013

Brazilian Society of Plant Breeding. Printed in Brazil

REVIEW

\title{
Food type soybean cooking time: a review
}

Deonisio Destro $^{1 *}$, Anderson Paranzini Faria ${ }^{1}$, Tainá Miranda Destro ${ }^{2}$, Ricardo Tadeu de Faria ${ }^{1}$, Leandro Simões Azeredo Gonçalves $^{1}$ and Wilmar Ferreira Lima ${ }^{1}$

Received 05 May 2013

Accepted 10 September 2013

\begin{abstract}
Soybean is an extensive crop that produces more protein per hectare and, compared to other sources, has the lowest protein cost. This turns soybean into one of the basic foods with the potential to fight malnutrition and hunger in the planet. Even though it represents the fourth crop in grain production in the world (261 million tons year $\left.{ }^{1}\right)$, most of its production is used as animal fodder. Currently, one of the greatest research challenges is to improve soybean production for human consumption. Cooking time is one the several characteristics that need improvement so that soybean can be used more extensively in our everyday diet. The objective of this work is to carry out a bibliographic review on the topic, to sensitize researchers in the area of soybean breeding about its importance.
\end{abstract}

Key words: genetic breeding, soybean food type, physical characteristics.

\section{INTRODUCTION}

Soybean (Glycine max (L.) Merrill) ranks fourth in world grain production (267 million tons year-1), after corn (Zea mays L.) (859 million tons year ${ }^{-1}$ ), wheat (Triticum aestivum L.) (655 million tons year ${ }^{-1}$ ), and rice (Oryza sativa L.) (469 million tons year ${ }^{-1}$ ) (USDA 2013a). Grains such as rice, wheat and corn make up the base of the human food pyramid (FAO 2012). As a legume (Poaceae), soybean has more protein than these grains, plus bioactive principles which beneficial biological effects on human's health have been largely studied.

Soybean is a source of protein with excellent nutritional characteristics. It shows a good essential amino acids balance but low sulphur amine acid methionine and cystine contents. Cereals have high sulfur amino acids, low lysine contents, which are high in soybean; therefore, the two grain types complement each other. Soybean is also an important source of iron, phosphate and potassium. As for vitamin contents, it is a source of vitamin B complex, with the exception of vitamin B12 (Carrão-Panizzi 1988).

Several studies have demonstrated that the consumption of soybean grains or soybean by products are frequently associated with reducing the risks of several diseases such as esophagus, lungs, prostrate, breast and colon/rectum cancer, cardiovascular diseases, osteoporosis, diabetes and menopause symptoms (Sorenson et al. 1994, Brandi 1997). It is believed that isaflavones (phytoestrogen) are mainly responsible for the observed benefits (Clapauch et al. 2002).

According to Carrão-Panizzi et al. (2003), the choice of cultivars which are genetically high in isoflavone content (phenolic heterocyclic compounds), and of cultivation sites, where the temperature is lower during grain filling, and grain hydrothermal treatment (cooking), with adequate temperature and time, promote the development of aglycone isoflavones, which are bio-available compounds responsible for beneficial effects on human health. They also guarantee the production of more adequate raw material for processing soybean-based functional foods.

Brazil is the second largest world producer of this legume, producing 82 billion tons; the US is the first with a production of 83 million tons, Argentina is third with 50 million tons, together with China (13 million tons), India (11 million tons) and Paraguay (9,3 million tons), being these countries the main world producers (USDA 2013b). Besides this large production and the recognized nutritional and nutraceutical qualities, the in natura consumption of soybean is highly limited, mainly in Eastern countries which are main producers. This limitation is mainly due to lack of habit, undesirable taste and odor (beany flavor),

\footnotetext{
${ }^{1}$ Universidade Estadual de Londrina (UEL), Departamento de Agronomia, Rodovia Celso Garcia Cid, PR 485, km 380, Campus Universitário, Londrina, 86.057-970, PR, Brazil

${ }^{2}$ Centro Universitário Filadélfia (UNIFIL), Departamento de Nutrição, Av. Juscelino Kubitschek, 1626, Londrina, 86.020-000, PR, Brazil. *E-mail: deonisiodestro@ yahoo.com
} 
after-cooking texture, and prolonged cooking time (Morais et al. 2001, Destro et al. 2003).

The unpleasant taste and smell have been assigned to lipoxygenase enzymes acting on the oxidation of lipids (Destro et al. 2003). Soybean maceration and cooking are procedures that facilitate enzyme inactivation (Berra 1974). Lipoxygenase are present in soybean grains in the form of three isoenzymes called lipoxygenase 1, 2 and 3. Genetic breeding can eliminate the presence of these isoenzymes. The alleles that determine the lack of these enzymes in the grains are recessive and have simple Mendelian inheritance. Locus lipoxygenage 1 is connected to that of lipoxygenase 2 , whereas the locus lipoxygenase 3 is independent (Kitamura et al. 1983).

Despite its high nutritional value, soybean has some antinutritional factors such as lectins, which are connected with the intestinal mucous cells, reducing nutrients absorption (Liener 1979 apud Bordingnon and Mandarino 1994), and trypsin and chymotrypsin inhibitors which are enzymes responsible for proteins digestion, which reduce soybean proteins digestion and bioavailability. These nutritional factors are easily inactivated by dry heat (toasting) thermal treatment or humid heat treatment (cooking) (Liener 1994).

Currently the world population is estimated in seven billion human beings. It is also estimated that by 2050 , the world population will reach approximately nine billion people. To meet this population demands for food, the FAO has estimated that current production must grow by $70 \%$ (Godfray et al. 2010). As soybean is an extensive crop which produces more protein by hectare, it becomes one of the potential basic foods to fight against malnutrition and hunger in the planet.

In the 1980's, Carrão-Panizzi (1988) proposed the use of soybean as part of the population's diet as the solution for the hunger problem in Brazil, considering the following advantages:

a) it is readily available for internal supply, and can be cultivated in any Brazilian region with a production organization that can respond to any agricultural incentive immediately;

b) it has the highest protein content, plus high caloric value and other nutritional qualities, compared to other extensive crops;

c) the cost of soybean protein is lower, compared to other sources;

d) it has high culinary plasticity, and can be part of practically all traditional recipes from the Brazilian cuisine, without altering the taste and appearance of the final products; and e) the consumption of soybean by humans has been growing continuously in the industrialized and developing countries.

However, soybean used directly for human consumption must have some special characteristics, including more quantity and more protein quality, less content and best quality oil, best taste, elimination or reduction of unpleasant odors and antinutritional factors, light-colored seeds (tegument, hilo and cotyledons), adequate grain size, high carbohydrate content and low cooking time (Carrão-Panizzi 1989, Vello 1992a).

Many soybean technological industrialized processes have as starting points the hydration and posterior cooking of the soybean (Morais et al. 2001). Soybean processing can promote changes in nutrients content, and, consequently, in nutritional quality. The immersion of grains in water, to soften them, and an adequate thermal treatment, increase protein digestibility as well as inactivate the proteases inhibitors and other antinutritional factors. According to Van der Poel et al. (1995), too much heat can destroy important amino acids and reduce the bioavailability of other nutrients. Overcooking leads to a reduction in protein quality, and a prolonged immersion leads to an increase in solid lixiviates (Wang et al. 1979, Walker and Kochhar 1982).

Destro et al. (2003) demonstrated that there is substantial genetic variability in soybean cooking time which can be used for the development of cultivars for human consumption with significant cooking time reduction. There are few works published in the world on soybean cooking time. The objective of this work is to carry out a bibliographic review on this topic to sensitize soybean breeding researchers of its importance.

\section{METHODOLOGIES FOR COOKING TIME AVALIATION}

The more frequently used methodology to measure the soybean cooking time is the modified Mattson machine (Mattson 1946), proposed by Jackson and Varriano-Marston (1981), used by Destro et al. (2003) and Meneguce et al. (2005), which is very cheap and simple. The technique consists in determining the cooking time by the percentage of grains cooked in the machine (50\%). After imbibition the 25 seeds were placed in individual capsules in the modified Mattson machine, which consists of 25 vertical rods, with a 90 gram weight on each grain, whose points rest on the soybean seed during the test. The machine is then taken to a recipient containing boiling distilled water. With time, the rods fall and perforate the grains. After the fall of the 13th rod the sample is considered cooked. The time taken from immersion of the machine in boiling water until the fall of the 13th rod is considered as the sample cooking time. 
Preliminary tests revealed that there was a mistake in the measuring at the start of the cooking time determination by the modified Mattson machine. The cold machine, when placed in the water, took time to heat, making the water bath lose 3 to $4{ }^{\circ} \mathrm{C}$. To avoid this inconvenience, the machine was previously heated in a water bath, without the seeds. After, with the machine heated the grains are inserted into the same for initial evaluation. The water bath was filled up with boiling water whenever necessary because of water loss through evaporation. The water temperature during the measurements remained around $98^{\circ} \mathrm{C}$ (Destro et al. 2003).

The soybean cooking time also can be measured by TA-XT2i apparatus, used by Morais et al. (2001), which is relatively expensive and complex. The technique consists in determining the seed texture assessed by the strength required to squash and extrude a cooked soybean grain, measured in Newtons second ${ }^{-1}\left(\mathrm{~N} \mathrm{seg}^{-1}\right)$. The results of a replication consist of a mean unit ten individual grains. The experimental unit consists of 50 cooked soybean grains, from which ten grains are removed and assessed individually. To determine the texture of an individual grain, a P25 $\mathrm{mm}$ probe (Cylinder Aluminium) is used attached to the Texture Analyser TA-XT2i apparatus, with the squashing speed calibrated at $2 \mathrm{~mm} \mathrm{seg}^{-1}$. Samples were prepared by immersing 50 seeds in $75 \mathrm{ml}$ distilled water for 18 hours at a mean temperature of $20{ }^{\circ} \mathrm{C}$; the water was replaced whenever necessary. The seeds selected for the analyses are intact without any damage or split seed coat. After an 18 hours imbibition, the water is drained from the samples, boiling $\left(90\right.$ to $\left.100^{\circ} \mathrm{C}\right)$ distilled water is added, and the grains are cooked for 60 or 90 minutes. The result of the texture is obtained by the strength value $\left(\mathrm{N} \mathrm{seg}^{-1}\right)$, which is used to squash the cooked soybean grain.

\section{COOKING TIME}

Grain acceptability for human consumption depends not only on its nutritional quality, but also on its cooking and hydration characteristics. Soybean cultivars with fast-cooking grains save time and energy (Yokoyama and Stone 2000). The thermal treatment of soybean grains has nutritional implications, since it develops adequate flavor (inactivating lipoxygenases) and texture for consumption, and inactivates antinutritional factors, improving protein digestibility. Prolonged cooking time causes minerals, vitamins and proteins loss (Silva et al. 2009).

Despite its significant nutritional composition, bean consumption has been reduced due to limited meal preparation time. Therefore, its importance for the development of cultivars with shorter cooking time becomes evident. The most important bean characteristics are: shorter cooking time, fast hydration capacity, teguments that do not break during hydration and cooking, and high volume expansion after cooking (Carbonell et al. 2003). Bressani (1993) adds that, besides the shorter cooking time and fast hydration, it has good grain size and color, grain color stability, thick sauce, good taste, good texture, moderately cracked grains and thin husk. These characteristics are normally taken into consideration by bean breeding programs. As for soybean, for the same purpose, the same characteristics should be considered as important.

Despite the large soybean production in Brazil, there are few studies which characterize appearance, aroma, texture and taste of grains from several soybean cultivars. That is, the grain sensorial profile is unknown although the importance of its physical and sensorial characteristics is well-known when consumers' acceptance of foods is discussed (Canto and Turatti 1989).

According to Vello (1992b), soybean can be classified into two types: grain type and food type. The grain-type soybean has average-size seeds and seedless mass of 10 to 19 grams, and is cultivated mainly to supply oil and bran production industries. There are two categories of foodtype soybean: small seeds, with 100 -seed mass inferior to 10 grams, consumed in "natto" (fermented soybean) or sprouts; large seeds, with 100-seed mass equal or greater than 20 grams. In these cases, mature grains in the form of soybean sweet (dark tegument) or salad (light-colored tegument), as tofu (cheese), misso (paste) or extract (milk). In addition, green pods with large seeds are consumed as edamame.

The introduction of soybean as basic food in the African countries homes has faced two great problems: the long cooking time and the unpleasant taste (Lokuruka 2011). In India, protein consumption by the general population is done basically through legumes broth, eaten together with wheat and rice. The use of soybean is not significant due to its low water absorption capacity, low spreadability, and prolonged cooking time. In Korea, soybean cultivars with black tegument are cooked with rice (Seakdong et al. 1995, Seakdong et al. 1997, Inyoul et al. 2004).

Soybean is one of the richest sources of protein; however, its prolonged cooking time makes its use more difficult. Soy dhal with sodium carbonate and sodium bicarbonate, at the $0.5 \%, 0.75 \%$ and $1 \%$ concentrations, reduced cooking time significantly. Sodium bicarbonate was most effective; however, it affected color and taste. Soy dhal must be soaked in sodium bicarbonate for at least six hours, and the highest the salt concentration the lowest the cooking time (Khetarpaul et al. 2005).

The addition of sodium chloride $(\mathrm{NaCl})$ to bean hydration water $\left(12\right.$ hours at $\left.25{ }^{\circ} \mathrm{C}\right)$ reduced cooking time. Cooking 
time for the Pérola cultivar was reduced from 37.8 minutes (without the addition of $\mathrm{NaCl}$ ) to 31 minutes, by adding $11 \mathrm{~g}$ of $\mathrm{NaCl}$ (in $50 \mathrm{~g}$ of grains and $200 \mathrm{ml}$ of distilled water), while the Uirapuru cultivar had its cooking time reduced from 49.5 minutes (without the addition of $\mathrm{NaCl}$ ) to 25 minutes with the addition of $16.75 \mathrm{~g}$ of $\mathrm{NaCl}$ (in 50 $\mathrm{g}$ of grains and $200 \mathrm{ml}$ of distilled water). Hydration with greater saline concentration than those mentioned above led to an increase in cooking time in the two cultivars (Bertoldo et al. 2008).

Despite the large soybean production in Brazil, many losses occur. An important loss is related to grains physical and chemical alterations by structural changes in their components due to storage, resulting in a product with high cooking resistance with changes in the organoleptic and nutritional properties. Several methods can be adopted to minimize this effect, among which the Cobalt-60 ionizing radiation constitutes a safe and efficient method to increase foods useful life (Siddhuraju et al. 2002).

When studying bean, Carbonell et al. (2003) found out that the differences related to cooking time are due to genetic and environmental components related to cultivation periods and sites and, possibly, to the interaction of these effects. Dalla Corte et al. (2003) reported that the nutritional and technological qualities of the bean are determined partly by genotype and influenced by environmental conditions during plant and grain development. According to these authors, the quality of these grains for cooking is affected by climatic factors such as high temperature during grain filling, cultivation practices, after harvest processing, storage conditions and processing technology.

Morais et al. (2001) studied the technological characteristic of soybean grains from six cultivars (BR-48, BR-58, BR-59, BR-61, BRS-133 e BRS-134) produced in two Paraná State counties (Mariópolis and Toledo), and found out that they differed among themselves in the evaluated characteristics ( including cooking time) which were affected differently by each environment.

When studying 20 inbreed lines originating from the crossing between the grain-type and food-type soybean, from the UEL soybean genetic breeding program, and using three EMBRAPA cultivars (BRS 133, BRS 155 and Embrapa 48) as controls, Meneguce et al. (2005) found some significant differences among the inbred lines for cooking time, during the two years of the study. In the first year, genotypes cooking time varied from 24.59 to 57.07 minutes and in the second year from 24.57 to 82.62 minutes. There was an interaction between Genotype $x$ Year (GY), indicating that the genotypes behaved differently regarding cooking time, for each year. It was possible to select the genotypes with large grains and small grains with short cooking time (adequate for foodtype soybean).

Vieira et al. (1997) analyzed six soybean cultivars: IAS-5, IGUAÇU, DAVIS, BR-16, IAS-4 and EMBRAPA-4 through a physical and technological evaluation using parameters such as apparent density, grains volume, 100-seeds mass, grain parts percentage, husk and hilo color, maceration time, amount of absorbed water, and cooking time. Minimum maceration time varied from 6 to 9 hours and maximum time from 12 to 15 hours; as for cooking time, variation was from 155 to 219 minutes. Cultivars BR-16 and IAS-5 had the shortest cooking times. Cooking time was determined by a cooker developed by Burr, according to the methodology described by Jackson and Varriano-Marston (1981) and modified by Cabral et al. (1995).

Destro et al. (2002) characterized agronomically and chemically 72 genotypes of food-type soybean. There was great genetic diversity among the genotypes studied, for all the evaluated characteristics. The genotype F 82-5782 has good characteristics as food such as large grains and yield compatible with commercial cultivars.

Destro et al. (2003) studied the genetic variability for cooking time in food-type soybean lines, grown in a greenhouse, and for lines obtained from the crossing between grain-type and food-type soybean (24 inbred lines), grown in the field (experiment 2). Findings from the two experiments showed a wide variability and cooking time varied from 26 to 170 minutes for the food-type lines and from 63 to 124 minutes for the crossed lines. They concluded that this variability may be used to obtain cultivars for human consumption, with an important reduction in cooking time. Giami (1997) studied some characteristics of three promising soybean lines in Nigeria and found that cooking time varied from 71 to 96 minutes, and that this time was reduced by $23 \%$ to $40 \%$, whenever seeds were immersed in water for 12 hours.

Silva et al. (2009) studied the chemical and physical composition of grain-type (BRS 133 e BRS 258) and foodtype (BRS 213, BRS 237 and BRS 216) grains during food processing and found that cultivars BRS 213 and BRS 216 showed the lowest cooking time, with 31.35 and 32.15 minutes, respectively.

Kilen and Hartwig (1978) found that the impermeability of soybean seed is due to three major recessive genes. From the viewpoint of soy for human consumption, hard seeds of soybean are considered undesirable for making cooking difficult. Thus, in soybean's ideotype for human consumption, soybean seeds should provide rapid absorption of water to be cooked. 


\section{FINAL COMMENTS}

A crop with exceptional characteristics for human nutrition, soybean has around $40 \%$ of protein besides other important nutrients, and is also a functional food with several health beneficial effects. American scientists were able to adapt it for the extensive mechanized cultivation, turning it into the crop we know today. In addition, Brazilian scientists were able to adapt it to the tropical and equatorial conditions, making possible for this culture to be cultivated under the most diverse conditions around the planet. As most soybean production is used for animal nutrition, one of the greatest research challenges is to improve it for human consumption.

Among the several characteristics that need improvement, cooking time stands out to make its utilization in people's everyday diet more frequent. This characteristic is important to improve soybean taste, therefore, improve its flavor and texture for consumption. Cooking also increases nutritional value, inactivating antinutritional factors, and, consequently, improving nutrients digestion. By reducing cooking time, energy and meal preparation time are also saved, important factors in modern life.

\section{Tempo de cozimento em soja alimento: uma revisão}

Resumo - A soja é a lavoura extensiva que mais produz proteína por hectare e, comparado a outras fontes, o custo da sua proteína é o menor. Isso faz da soja um dos alimentos básicos potenciais na luta contra a subnutrição e a fome do planeta. Apesar de ser a quarta cultura em produção de grãos (261 milhões $t$ ano ${ }^{-1}$ ) no mundo, a maioria dessa produção destina-se a nutrição animal. Um dos grandes desafios da pesquisa é melhorá-la para o consumo humano. Dentre as várias características que precisam ser melhoradas para que ocorra uma maior utilização da soja na dieta cotidiana, destaca-se, o tempo de cozimento. Este trabalho tem como objetivo fazer uma revisão bibliográfica deste tema, para sensibilizar os pesquisadores da área de melhoramento de soja de sua importância. Palavras-chave: Melhoramento genético, soja alimento, características fisicas.

\section{REFERENCES}

Berra R (1974) Efecto del remojo en algunas propriedades físicas, bioquímicas y organolépticas de la soja. Tecnologia de Alimentos 9: $76-84$

Bertoldo JG, Coimbra JLM, Silveira CB and Toaldo D (2008) Efeito de diferentes concentrações salinas na redução do tempo de cocção de feijão (Phaseolus vulgaris L.). Biotemas 21: 39-44.

Bordingnon JR and Mandarino JMG (1994) Soja: composição química, valor nutricional e sabor. EMBRAPA, CNPSo, Londrina, 32p.

Brandi ML (1997) Natural and synthetic isoflavones in the prevention and treatment of chronic disease. Calcified Tissue International 61: S5-S8

Bressani R (1993) Grain quality of common beans. Food Reviews International 9: 237-297.

Cabral LC, Serna-Saldivar SO and Tinsley AM (1995) Effects of dehulling and storage conditions on cooking requirements and chemical composition of soybeans. Archivos Latinoamericanos de Nutricion 45: $36-45$.

Canto WL and Turatti JM (1989) Produção e mercado de produtos intermediários de soja no Brasil. Boletim do Centro de Pesquisa e Processamento de Alimentos 2: 111-139.

Carbonell SAM, Carvalho CRL, Azevedo Filho JA and Sartori JA (2003) Qualidade tecnológica de grãos de genótipos de feijoeiro cultivados em diferentes ambientes. Bragantia 62: 369-379.

Carrão-Panizzi MC (1988) Valor nutritivo da soja e potencial de utilização na dieta brasileira. EMBRAPA CNPSo, Londrina, 13p.

Carrão-Panizzi MC (1989) Breeding soybean for human consumption. $4^{\text {th }}$ World Soybean Research Conference. CAB, Buenos Aires, p.
1101-1105.

Carrão-Panizzi MC, Simão AS and Kikuchi A(2003) Efeitos de genótipos, ambientes e de tratamentos hidotérmicos na concentração de isoflavonas agliconas em grãos de soja. Pesquisa Agropecuária Brasileira 38: 897-902.

Clapauch RM, Ricardo MR, Julião MASG, Loureiro CKC, Giarodoli PB, Pinheiro AS and Harrigan AR (2002) Fitoestrogênios: posicionamento do Departamento de Endocrinologia Feminina da Sociedade Brasileira de Endocrinologia e Metabologia (SBEM). Arquivos Brasileiros de Endocrinologia e Metabologia 46: 679-695.

Dalla Corte A, Moda-Cirino V and Scholz MBS (2003) Environment effect on grain quality in early common bean cultivars and lines. Crop Breeding and Applied Biotechnology 3: 193-202.

Destro D, Miranda ZFS, Martins AL, Mandarino JMG, Miranda LA, Souza HM, Favoreto R and Montalván R (2002) Agronomic and chemical characterization of soybean genotypes for human consumption. Crop Breeding and Applied Biotechnology 2: 599-608.

Destro D, Bizeti HS, Marega Filho, M, Morais LK, Tróia C and Montalván R (2003) Genetic variability for traits related to cooking time in soybean. Crop Breeding and Applied Biotechnology 3: 275-280.

FAO (2012) Food and Agriculture Organization of the United Nations. Available at $<$ http://www.fao.org/docrep/011/ai474e/ai474e02.htm> Accessed on Jan 31, 2012.

Giami SY (1997) Evaluation of selected food characteristics of three advanced lines of Nigerian soybean (Glycine max (L.) Merr.). Plant Foods for Human Nutrition 50: 17-25.

Godfray HC, Beddington JR, Crute IR, Haddad L, Lawrence D, Muir JF, Pretty J, Robinson S, Thomas SM and Toulmin C (2010) Food security: the challenge of feeding 9 billion people. Science 327: 812-818. 
Inyoul B, Wonyoung H, Sungtaeg K, Doochull S, Myounggun C, Seakwan O, Sangouk S, Duckyong S and Soonchul K (2004) A new Black soybean cultivar, "Cheongja 2" with green cotyledon, early maturity and high anthocyanin. Korean Journal of Breeding 36: 385-386.

Jackson GM and Varriano-Marston E (1981) Hard-to-cook phenomenon in beans: effects of accelerated storage on water absorption and cooking time. Journal of Food Science 46: 799-803.

Khetarpaul N, Goyal R and Garg R (2005) Effect of salt solution pretreatment on the cooking quality and consumer acceptability of soy dhal. British Food Journal 107: 344-352.

Kilen TC and Hartwig EE (1978) An inheritance study of impermeable seed in soybeans. Field Crop Research 39: 65-70.

Kitamura K, Davies CS, Kaizuma N and Nielsen NC (1983) Genetic analysis of a null-allele for lipoxygenase 3 in soybean seeds. Crop Science 23: 924-927.

Liener IE (1994) Implications of antinutritional components in soybean foods. Critical Reviews in Food Science and Nutrition 34: 31-67.

Lokuruka MNI (2011) Effects of processing on soybean nutrients and potential impact on consumer health: an overview. African Journal of Food, Agriculture, Nutrition and Development 11: 5000.

Mattson S (1946) The cookability of yellow peas. Acta Agriculturae Suecana 1: 185.

Meneguce B, Faria RT, Destro D, Fonseca Junior NS and Faria AP (2005) Interação genótipo $\mathrm{x}$ ano para tempo de cozimento e sua correlação com a massa e percentagem de embebição em soja tipo alimento. Semina: Ciências Agrárias 26: 463-476.

Morais LK, Destro D, Fonseca Junior NS, Carbonell SM, Miranda LA and Pinheiro JB (2001) Genotype x environment interaction and correlation among technological traits of soybean grains. Crop Breeding and Applied Biotechnology 1: 245-254.

Seakdong K, Eunhi H, Sukha L, Yealkyu S, Yongho K, Keumyong P, Yonghwan R, Kyungjin C and Yunsun KA (1995) Black seed coated, large seeded and high yielding soybean variety for cooking with rice "Geomjeongkong 1". RDA Journal of Agricultural Science, Upland e Industrial Crops 37: 135-138.

Seakdong K, Yongho K, Keumyong P, Hongtae Y, Sukha L, Yealkyu S, Hongsig K, Yeongho L, Euiho P, Younghyun H, Eunhi H and Yunsun K (1997) A new soybean variety with a Black seed coat for cooking with Rice, "Geomjeongkong 2", with good quality and disease resistance.
RDA Journal of Crop Science 39: 108-111.

Siddhuraju P, Makkar HPS and Becker K (2002) The effect of ionising radiation on antinutritional factors and the nutritional value of plant materials with reference to human and animal food. Food Chemistry 78: $187-205$.

Silva JB, Carrão-Panizzi MC and Prudêncio SH (2009) Chemical and physical composition of grain-type and food-type soybean for food processing. Pesquisa Agropecuária Brasileira 44: 777-784.

Sorenson RL, Brelje TC and Roth C (1994) Effect of tyriosine kinase inhibitors on islet od Langerhans: evidence for tyrosine kinases in the regulation of insulin secretation. Endocrinology 134: 1975-1978.

USDA (2013a) United States Department of Agriculture. Available at < http://www.fas.usda.gov/grain/default.asp > Accessed on Aug $14,2013$.

USDA (2013b) United States Department of Agriculture. Available at $<$ http://www.fas.usda.gov/oilseeds/default.asp $>$ Accessed on Aug 14, 2013.

Van Der Poel AFB, Verstegen MWA and Tamminga S (1995) Chemical physical and nutritional effects of feed processing technology. In: Western Nutrition Conference. Saskatoon. Edmonton, p.70-86.

Vello NA(1992a) Métodos de melhoramento de soja. In Anais do simpósio sobre a cultura e produtividade da soja. FEALQ, Piracicaba, p. 82-101.

Vello NA (1992b) Ampliação da base genética do germoplasma e melhoramento da soja na ESALQ. In Anais do simpósio sobre a cultura e produtividade da soja. FEALQ, Piracicaba, p.60-81.

Vieira CR, Cabral LC and Paula CO (1997) Caracterização física e tecnológica de seis cultivares de soja plantadas no Brasil. Ciência e Tecnologia de Alimentos 17: 291-294.

Walker AF and Kochhar N (1982) Effect of processing including domestic cooking on nutritional quality of legumes. Proceedings of Nutrition Society 41: 41-51.

Wang HL, Swain EW, Hesseltine CW and Health HD (1979) Hydration of whole soybeans affects solids losses and cooking quality. Journal of Food Science 44: 1510-1513.

Yokoyama LP and Stone LF (2000) Cultura do feijoeiro no Brasil: características da produção. Embrapa Arroz e Feijão, Santo Antônio de Goiás, 228p. 